\title{
INVESTIGATING FACTORS INFLUENCING CLASS ATTENDANCE AND PERFORMANCE OF FIRST-YEAR ECONOMICS STUDENTS
}

\author{
C. Swanepoel* \\ https://orcid.org/0000-0003-0906-8995
}

\author{
R. Beukes* \\ D. $\mathbf{Y u}^{*}$
}

https://orcid.org/ 0000-0001-9813-7897

*University of the Western Cape

Department of Economics

Cape Town, South Africa

\section{ABSTRACT}

The academic success of first-year Economics students has been examined in many South African studies in Economic Education. These studies controlled for differences in demographic characteristics, last school examination (Matric) subjects and results, as well as lecture and tutorial attendance when investigating differences in students' performance. While there is an abundance of international studies investigating the main reasons for attendance or non-attendance, these studies are rare in the South African context, especially in the field of Economics. Hence, this study fills the existing local research gap by investigating factors influencing lecture attendance as well as their possible impact on the performance of first-year Microeconomics students at the University of the Western Cape.

The key empirical findings suggest that both lecture and tutorial attendance had a positive and significant impact on both the likelihood of qualifying to write the examination as well as the examination mark. In addition, students who enrolled in Economics in Matric and obtained better marks in first-year Macroeconomics in the previous semester performed significantly better in the Microeconomics examination. It was also found that the main reasons for not attending lectures are academically related, with the top reason being "busy studying for tests". Furthermore, students who regarded tutorials as a replacement for lectures significantly suffered nearly five marks lower in the examination.

We recommend revisions to teaching methods and making lecture attendance compulsory and part of assessments. Furthermore, given lecture attendance is low, revisions to timetables should be considered and expanded transportation be made available to students. Lastly, students should be given the necessary time management tools to adjust to greater workloads at university.

Keywords: Economics education, class attendance, academic performance 


\section{INTRODUCTION}

Over the last couple of decades, factors influencing the success of first-year Economics students have been comprehensively studied and researched. These studies focused on a wide range of factors including personal characteristics (e.g., gender, population group and age), school performance specifically Grade 12 (Matric) entry points and school subject choices (such as Mathematics, Mathematical Literacy, English home language and Economics) and university characteristics (e.g., campus residence, type and duration of programmes). The research also considered study characteristics like lecture attendance, tutorial attendance, study hours as well as intervention programmes like mentorship and student engagement; all these factors were found to have a positive impact on students' academic performance.

In particular, higher lecture attendance is associated with significantly better academic performance as expected, but Romer (1993) found that on average one-third of students are not in class. Hence, the following question comes to mind: why are students not in class? Various international studies (to be reviewed later) examined factors relating to low lecture attendance, such as course characteristics and perceived quality of lecturers and lectures, student motivation, and student characteristics like age, gender, grade point average (GPA) and parttime work status. However, why lecture attendance is low is not studied extensively in the existing local literature besides a few to note.

Teaching and learning environments have changed dramatically over the last two decades. Technology has opened the doors to online blending learning, and significantly changed how academics teach and assess students' learning. Students have access to PowerPoint slides, videos, voice recordings and other resources, which help facilitate greater engagement with students. Nonetheless, access to blended learning should enhance the offering to students but not adversely affect class attendance if used correctly (Riffell and Sibley 2004). Therefore, this study aims to fill the local research gap in Economic Education by investigating factors that influence lecture attendance of first-year Economics students and how these factors influence their academic performance. The specific research objectives are as follows:

- To conduct descriptive statistics analysis on personal and study characteristics of the students.

- To investigate the main reasons of absence from lectures; these causes are classified into three main categories, namely academic, institutional and personal causes.

- To conduct multivariate econometric analysis to investigate the impact of various factors on academic performance. 
Our forthcoming empirical findings first support the existing literature that lecture and tutorial attendance matter significantly for academic performance. Further, we find that the major reasons students are absent from lectures are academic in nature. The lecture day and time also have a significant impact on lecture attendance.

\section{REVIEW OF PAST EMPIRICAL STUDIES}

\section{Local studies}

The first local study on Economics students' performance was conducted by Edwards (2000) at the University of Cape Town (UCT) by distinguishing students from disadvantaged schools from those attending more privileged schools. Unfortunately, this study did not investigate class attendance. Van Walbeek (2004) investigated the academic performance of UCT first-year Economics students; he found that, on average, an additional lecture attended led to a small yet significant 1.5 point increase of final mark, ceteris paribus. ${ }^{1}$

Parker (2006) investigated first-year Economics performance in five anonymous universities and found that male English-speaking students who studied at least two hours per week outside classes enjoyed significantly better performance. Van der Merwe (2006) showed that demographic and school characteristics, and even motivational factors (e.g., enrolled the course voluntarily to obtain extra credit; purchased the prescribed textbook early in the semester) did not have any statistically significant impact on first-year Economics performance at the Durban Institute of Technology.

Smith and Edwards (2007) investigated the impact of an academic development programme (equivalent to a 4-year extended programme) at UCT. They founded that the extended programme helped improve students' learning, English language and writing skills, and in general the extended programme students outperformed the 3-year mainstream programme students in both first- and second-year Economics studies, ceteris paribus. A subsequent study by Smith (2009) on UCT first-year Microeconomics students over a 6-year period confirmed the results of Smith and Edwards (2007).

Horn and Jansen (2009) examined the impact of both lecture and tutorial attendance. Their empirical findings confirmed that both higher lecture and tutorial attendance, along with better Matric results, had a significantly positive impact on first-year Economics performance at Stellenbosch University (SU). Horn, Jansen, and $\mathrm{Yu}$ (2011) is focused on second-year performance at SU; while lecture and tutorial attendance remained significant explanatory variables, first-year performance also had a significant positive impact. Dlomo et al. (2011) 
found that both attendances only had a significant impact on the University of the Western Cape (UWC) first-year Economics students' probability to qualify to final examination, but other factors such as gender, matriculation under the 2008 National Senior Certificate (NSC) curriculum, part-time work status and study hours were the key explanatory variables influencing exam marks.

Schreiber and Yu (2016), using the 2013 South African Survey of Student Engagement (SASSE) data, found that two out of 10 engagement indicators - collaborative learning and higher-order learning - positively and significantly impacted on academic performance of undergraduate students at UWC. Dos Reis and Yu (2018) found that first-year UWC Economics students who participated in the peer-mentoring programme on average scored four points higher in both examination and final marks, ceteris paribus. Moreover, tutorial attendance had a positive impact on academic performance.

To the authors' knowledge, only four local studies examined causes of low class attendance. Jordaan (2009) found that the three dominant reasons for students attending lectures at the University of Pretoria (UP) were "to find out what I am supposed to learn", "to make sure I don't miss anything important" and "to make the knowledge meaningful". Moreover, the provision of online learning resources did not adversely affect lecture attendance, and there was a positive association between lecturer evaluation and lecture attendance. The latter finding was also confirmed by Wadesango and Machingambi (2011) in their study on student absenteeism at three South African universities. The other reasons for absenteeism included, amongst others, part-time work commitment, preference to spend time with friends and peers, lack of interest in the subject and the need to study for tests and complete assignments.

Schmulian and Coetzee (2011) found the main reasons for lecture non-attendance in an Accounting module at the UP included timetable clashes, transportation, and studying for course work and tests. Lastly, Braak (2015) found that lack of motivation, illness and family commitments were the top reasons for non-attendance in a Hospitality Management module at a private college.

\section{International studies}

Various international studies also found a significant positive relationship between lecture attendance and academic performance (Romer 1993; Devadoss and Foltz 1996; Paisey and Paisey 2004; Massingham and Herrington 2006; Woodfield, Jessop, and McMillan 2006; Moore 2006). Focusing on studies that examined what drove the students' decision to attend lectures, Vidler (1980) tested the correlation between academic curiosity, class attendance and course performance of undergraduate students. Students who attended classes frequently when 
attendance was not mandatory were more academically curious and showed better performance. Moreover, Romer (1993) found that Economics students' absenteeism was higher in core courses where students generally were required to take the course as opposed to elective courses where there was some choice demonstrating their interest in a course.

Devadoss and Foltz (1996) examined students' performance in Agricultural Business and Economics at four American universities. The notable factors affecting class attendance and academic performance were motivation, prior GPA, self-finance of studies, work hours, nature of lectures and quality of teaching. Similarly, Friedman, Rodriguez, and McDomb (2001) found that motivation related to own subject choice had a positive correlation with lecture attendance.

Longhurst (1999) examined 15 reasons for non-attendance at a further education college. The general finding was the top reasons for absence were illness, medical appointments and weather conditions. Massingham and Herrington (2006) investigated the reasons behind lecture non-attendance of a third-year commerce course at Wollongong University, and found that while there were no health or lifestyle factors impacting attendance, students' motivation and attitude towards learning came to the fore as important influencers of attendance. Motivational factors were cited as perhaps of greater importance for non-compulsory classes than those that were compulsory. Likewise, Kottasz (2005) found both extrinsic (e.g., importance to get good grades) and intrinsic (e.g., genuine interest in course content) motivation were both important reasons for not missing classes, whereas the main reasons for missing classes were illness, transport problems and class times not always being right.

Dolnicar (2005) distinguished two groups of students at an Australian university: idealists who were older with work experience and enjoyed lectures, and pragmatists who were younger and attended lectures to obtain the necessary information. The main reasons of both groups for attending classes were "find out what I am supposed to learn", "don't want to miss important information" and "find out about assessment tasks". On the contrary, Moore (2006) found that whilst most Biology students understood the importance of class attendance to improve their performance, many believed they should receive credit for attending, and so their attendance was influenced by such belief. Moore, Armstrong, and Pearson (2008) also found that students with low motivation level had lower lecture attendance at a university in Ireland.

Wyatt (1992) found that the main factors driving first-year college students' high absenteeism included the general dislike of classes, insufficient time spent on studying, high frequency of alcohol consumption and being female. The latter finding was opposite of Friedman et al. (2001) who offered no correlation between gender and class attendance frequency. Woodfield et al. (2006) specifically investigated attendance rates by gender; For male students, more absences were associated with significantly higher level of extraversion 
but lower levels of conscientiousness and verbal/numerical ability; for female students, high absence frequency was correlated with lower age at entry, lower levels of agreeableness and conscientiousness.

Course characteristics and lecturer/lecture quality were investigated in some studies. Romer (1993) found that non-attendance was lower in smaller classes and perception of quality was important for attendance, while Devadoss and Foltz (1996) noted factors such as the quality of lecturers, class duration, time of lecture, level of course difficulty and the course having an attendance requirement all had a significant impact on class attendance. Friedman et al. (2001) found that small enrolment size and course type were correlated to attendance. Paisey and Paisey (2004) looked at the class attendance of Financial Accounting students at a Scottish university, and found that factors such as late afternoon class time and imminent coursework assignment submission deadlines (along with other factors like financial hardships and work commitment) were commonly cited as reasons for low attendance.

Lastly, as academics move to more blended learning approaches, Riffell and Sibley (2004) evaluated whether a hybrid (combination of online and face-to-face contact) introductory science course at Michigan State University helped boost attendance and hence performance. The results indicated online assignment completion rate was higher than traditional lecture attendance rate. Moreover, the hybrid course format was found to be effective in increasing class attendance, especially the higher-level students compared to first-year freshmen.

\section{METHODOLOGY AND DATA}

\section{Theoretical model}

The education production function approach, first introduced by Siegfried and Fels (1979), is employed for this study. A production function measures outcomes based on the respective inputs. Outcomes vary from measurement of learning, student attitudes, impact of understanding on behaviour and distribution of benefits. Learning inputs are divided into various categories: student input, faculty input, college environment and student effort.

We adapt these categories as follows in this study: the outcome variable is examination mark of first-year Microeconomics (module code: ECO151). We also control for these important inputs: first, student input variables include demographic characteristics such as age, gender and population group. Secondly, since ECO151 is a second-semester course (ECO152 Macroeconomics is offered in the first semester), both school attainment characteristics and ECO152 performance are included as other student input variables. To control for faculty input and college environment, we include variables such as campus residence status, enrolled degree 
programme and duration.

We measure students' effort with lecture attendance, tutorial attendance and weekly study hours. Lecture attendance was captured in two ways: self-reported attendance frequency in a questionnaire and electronically captured attendance with the aid of a student card reader over a three-week period (eight attendances were captured). Finally, as per our intended contribution to existing local literature, we include the main causes of low lecture attendance in connection with academic, institutional and personal reasons.

\section{Empirical model}

Since not everyone is eligible to write the final examination, the results derived from the Ordinary Least Squares (OLS) will be biased due to sample selection problems. Hence, a twostep Heckman approach is adopted. In the first step, a probit analysis is conducted to identify factors determining if the students qualified and wrote the final examination, whereas the second step investigates factors influencing their performance in the examination.

\section{First-year Economics modules at UWC}

In 2019, the Department of Economics offered two semesterised first-year modules to full-time students, namely ECO151 (second semester) and ECO152 (first semester). The ECO151 students were divided into four lecturing groups; in each group, three 1-hour lectures were taught per week, during the 13-week semester. Whereas all ECO152 students are eligible to write the final examination, in the case of ECO151, students must obtain a continuous assessment mark (CAM) of 40 or above to be eligible to write the final examination. In 2019, the continuous assessment tasks included four tutorials, two modules tests and one online multiple-choice test, while the final mark was calculated as $0.5 \times \mathrm{CAM}+0.5 \times$ exam mark.

\section{Data}

In 2019, a total of 952 students enrolled ECO151. The UWC Student Administration System (SASI) was used to extract information on students' demographic characteristics, Grade 12 (Matric) subjects and entry points, and campus residence status. Since Matric information was incomplete in five students on SASI, final sample size was reduced to 947 . The UWC entry points were derived by a weighted system of declining scale to award points for symbol obtained in each subject, and the maximum attainment total entry points are 65 (for detailed explanation, see Dos Reis and Yu 2018, 240-241).

Since information on work status, work hours, weekly hours spent on studying the course materials and reasons for not attending lectures are not available on SASI, we designed a 
questionnaire to capture the abovementioned information. Hard copies of the survey were handed out to students in the final tutorial of the semester to boost response rate, given it was compulsory for students to submit assignment exercises during the tutorial periods. Out of the 947 students, 672 completed and submitted the survey (the response rate was 71\%).

The UWC Marks Administration System (MAS) captures information on students' marks in each assessment task, CAM, examination mark and final mark. Lastly, data from the abovementioned three sources (survey, SASI and MAS) were combined into one overall data file in Stata format before the empirical findings were derived.

\section{EMPIRICAL FINDINGS}

\section{Descriptive statistics}

Table 1 shows that the majority of students were aged 19-20 years at the time of enrolling ECO151, as they accounted for 60 per cent of the sample. The female share was slightly more dominant (54\%), while the African and Coloured racial shares were the greatest (56\% and 39\% respectively). Nearly 52 per cent reported speaking any African language at home whereas 42 per cent spoke English. About 9 per cent of the students claimed they stayed at campus residence, while 56 per cent enrolled at UWC for the first time in 2019. Lastly, the table indicates that approximately two-thirds enrolled a 3-year programme; BCom 3-year programme was most popular (29\%), followed by BCom 4-year extended programme (24\%).

Table 1: Profile of the ECO151 students (\%)

\begin{tabular}{|l|c|}
\hline Age & \\
\hline $17-18$ years & 9.93 \\
\hline 19 years & 35.27 \\
\hline 20 years & 25.03 \\
\hline 21 years & 12.46 \\
\hline 22 years or above & 17.31 \\
\hline Mean (years) & 20.19 \\
\hline Gender & \\
\hline Male & 46.15 \\
\hline Female & 53.85 \\
\hline Race & \\
\hline African & 56.07 \\
\hline Coloured & 39.28 \\
\hline Asian/Indian & 3.38 \\
\hline White & 1.27 \\
\hline Home language & \\
\hline English & 42.03 \\
\hline Afrikaans & 6.34 \\
\hline
\end{tabular}




\begin{tabular}{|l|r|}
\hline Any African language & 51.64 \\
\hline Staying at campus residence & \\
\hline Yes & 8.76 \\
\hline No & 91.24 \\
\hline Programme enrolled & \\
\hline BAdmin 3-year & 0.32 \\
\hline BCom 3-year & 29.25 \\
\hline BCom Accounting 3-year & 13.62 \\
\hline BCom Financial Accounting 3-year & 14.26 \\
\hline BCom Law 3-year & 6.34 \\
\hline BSc Maths 3-year & 0.32 \\
\hline BCom 4-year & 24.29 \\
\hline BCom Accounting 4-year & 11.62 \\
\hline Years of enrolment at UWC & \\
\hline First year & 56.18 \\
\hline Second year & 34.32 \\
\hline More than two years & 9.50 \\
\hline
\end{tabular}

With regard to the students' school characteristics, Table 2 shows that more than 60 per cent of the ECO151 students matriculated in Western Cape schools, while mean entry points was 40.09 . Overall, 82.5 per cent of the students enrolled at least one commerce subject, namely Accounting (71\%), Business Studies (50\%) and Economics (30\%). Moreover, a very high share of 94.72 per cent enrolled Mathematics (instead of Mathematical Literacy) in Matric.

Table 2: Matric characteristics of ECO151 students (\%)

\begin{tabular}{|l|r|}
\hline Province of exam authority & \\
\hline Western Cape & 62.62 \\
\hline Eastern Cape & 13.62 \\
\hline Gauteng & 9.40 \\
\hline Other provinces & 13.83 \\
\hline Overseas & 0.53 \\
\hline Entry points & \\
\hline Below 35 points & 11.19 \\
\hline $35-39$ points & 29.04 \\
\hline $40-44$ points & 44.77 \\
\hline 45 points or above & 14.99 \\
\hline Mean (points) & 40.09 \\
\hline Proportion enrolled in each subject & \\
\hline Accounting & 71.17 \\
\hline Business Studies & 49.84 \\
\hline Economics & 29.57 \\
\hline Life Sciences & 49.84 \\
\hline Physical Sciences & 47.62 \\
\hline Mathematics & 94.72 \\
\hline English home language & 64.00 \\
\hline
\end{tabular}




\begin{tabular}{|l|r|}
\hline Afrikaans home language & 8.13 \\
\hline Any African home language & 28.19 \\
\hline
\end{tabular}

Table 3 shows that only 5 per cent of the ECO151 students repeated the module in 2019. It was mentioned in section 3.1 that the attendance of eight lectures in the first three weeks of the second term was captured by a digital device. A worrying finding is that 37 per cent did not even attend one lecture, while 46 per cent only attended between one and four lectures. The mean number of attendance was low at 2.07. In contrast, tutorial attendance was very high, with two-thirds attending all four tutorials and mean attendance was 3.34. These results are expected, as it was previously mentioned that students were required to submit assessments during the tutorial period. Tutorial attendance was thus "compulsory" it gave students some merit to attend (as also found by Devadoss and Foltz 1996 as well as Moore 2006).

Table 3: Study characteristics and academic performance of ECO151 students (\%)

\begin{tabular}{|c|c|}
\hline Repeater of ECO151 & \\
\hline Yes & 5.07 \\
\hline No & 94.93 \\
\hline \multicolumn{2}{|l|}{ Lecture attendance } \\
\hline None & 37.17 \\
\hline Once or twice & 24.29 \\
\hline Three to four times & 21.64 \\
\hline Five to six times & 13.83 \\
\hline Seven times & 3.06 \\
\hline Mean (number of attendance) & 2.07 \\
\hline \multicolumn{2}{|l|}{ Tutorial attendance } \\
\hline None & 6.23 \\
\hline Once or twice & 9.51 \\
\hline Three times & 18.48 \\
\hline Four times & 65.79 \\
\hline Mean (number of attendance) & 3.34 \\
\hline \multicolumn{2}{|c|}{ EC0151 Continuous assessment mark (CAM) } \\
\hline Below 40 marks & 11.41 \\
\hline 40-49 marks & 10.77 \\
\hline 50-59 marks & 28.19 \\
\hline $60-69$ marks & 27.88 \\
\hline 70-74 marks & 10.03 \\
\hline 75-100 marks & 11.72 \\
\hline Mean (mark) & 57.03 \\
\hline \multicolumn{2}{|l|}{ EC0151 Examination mark } \\
\hline Did not write & 0.72 \\
\hline Below 40 marks & 10.25 \\
\hline 40-49 marks & 29.32 \\
\hline 50-59 marks & 29.32 \\
\hline
\end{tabular}




\begin{tabular}{|l|r|}
\hline 60-69 marks & 17.40 \\
\hline 70-74 marks & 5.01 \\
\hline 75-100 marks & 7.99 \\
\hline Mean (mark) & 53.88 \\
\hline EC0151 Final mark & 11.40 \\
\hline Fail: Did not qualify to write exam & 0.63 \\
\hline Fail: Did not write exam & 13.10 \\
\hline Fail: Below 50 marks & 38.12 \\
\hline Pass: 50-59 marks & 22.91 \\
\hline Pass: 60-69 marks & 6.55 \\
\hline Pass: 70-74 marks & 7.29 \\
\hline Pass: 75-100 marks & 58.05 \\
\hline Mean (mark) & \\
\hline ECO152 Final mark & 16.58 \\
\hline Failed: Below 50 marks & 40.65 \\
\hline Pass: 50-59 marks & 27.24 \\
\hline Pass: 60-69 marks & 8.87 \\
\hline Pass: 70-74 marks & 6.65 \\
\hline Pass: 75-100 marks & 56.97 \\
\hline Mean (mark) & \\
\hline
\end{tabular}

Table 4 provides a more detailed breakdown of lecture attendance by showing the number of students per group attending each lecture in weeks 8 and 9. Class attendance was much lower in on Mondays 15:30-16:30, Fridays 10:50-11:50 and Fridays 12:00-13:00. We will revert back to these results later when examining the reasons why students did not attend lectures.

Table 4: Number of students attending each lecturing group in two selected weeks

\begin{tabular}{|l|l|c|c|c|}
\hline \multirow{4}{*}{ Group 1 } & & Tue 08:30-09:30 & Wed 13:10-14:10 & Thu 12:00-13:00 \\
\cline { 2 - 5 } & Week 8 & 110 & 76 & 77 \\
\cline { 2 - 5 } & Week 9 & 97 & 56 & 91 \\
\hline \multirow{4}{*}{ Group 2 } & & Mon 10:50-11:50 & Tue 13:10-14:10 & Fri 10:50-11:50 \\
\cline { 2 - 5 } & Week 8 & 134 & 52 & 36 \\
\cline { 2 - 5 } & Week 9 & 114 & 63 & 46 \\
\hline \multirow{3}{*}{ Group 3 } & & Mon 09:40-10:40 & Tue 14:20-15:20 & Fri 12:00-13:00 \\
\cline { 2 - 5 } & Week 8 & 95 & 56 & 24 \\
\cline { 2 - 5 } & Week 9 & 77 & 63 & 27 \\
\hline \multirow{3}{*}{ Group 4 } & & Mon 15:30-16:30 & Wed 12:00-13:00 & Thu 13:10-14:10 \\
\cline { 2 - 5 } & Week 8 & 44 & 81 & 65 \\
\cline { 2 - 5 } & Week 9 & 41 & 69 & 60 \\
\hline
\end{tabular}

As shown in Table 3, out of 947 students, 839 (or 88.6\%) obtained a CAM of at least 40 marks and qualified to write the final examination. With regard to the latter, 833 students wrote this final assessment; the average mark was 53.88 and the majority of them obtained 40-59 marks (nearly $60 \%$ share). Regarding the final mark, pass rate of the module was 74.87 per cent, with 
a mean of 58.05 marks. About 61 per cent obtained 50-69 marks, while slightly over 7.29 per cent attained a distinction. The bottom rows show the ECO151 students' performance in ECO152 in the first semester; pass rate was 83.42 per cent with a mean final mark of 56.97. Lastly, although not shown in the table, 70.96 per cent of ECO151 students passed both ECO151 and ECO152, and the correlation coefficient between ECO151 and ECO152 final marks was 0.68 , i.e., there was a positive and moderately strong relationship between the two marks.

Table 5 shows key findings from the survey. First, about 15 per cent reported they were working at the time of the survey (weekly median and mean work hours were 10 and 17 respectively). About two-thirds relied on bursaries or scholarships to pay the study fees, while nearly 30 per cent relied on family members for financial support to pay the study fees.

Table 5: Key findings from the survey (\%)

\begin{tabular}{|c|c|}
\hline Work status & \\
\hline Do not work & 84.08 \\
\hline Work as UWC tutor & 1.64 \\
\hline Work part-time off-campus & 12.65 \\
\hline Work full-time off-campus & 1.19 \\
\hline Unspecified & 0.45 \\
\hline \multicolumn{2}{|l|}{ Primary source to pay study fees } \\
\hline Student's family & 29.61 \\
\hline Student himself/herself & 3.13 \\
\hline Bursary & 63.10 \\
\hline Scholarship & 2.38 \\
\hline Unspecified & 1.79 \\
\hline \multicolumn{2}{|c|}{ Distance between residence and campus } \\
\hline Campus residence & 22.17 \\
\hline Private residence close to campus & 16.22 \\
\hline Within $5 \mathrm{~km}$ from campus & 5.06 \\
\hline 5-10km from campus & 10.57 \\
\hline 10-20km from campus & 17.41 \\
\hline 20-30km from campus & 14.58 \\
\hline More than $30 \mathrm{~km}$ from campus & 13.99 \\
\hline \multicolumn{2}{|c|}{$\begin{array}{l}\text { Transport mode (if not staying on campus residence or } \\
\text { private residence close to campus) }\end{array}$} \\
\hline Own car & 23.91 \\
\hline Lift club & 25.85 \\
\hline Bus & 16.91 \\
\hline Mini-bus taxi & 17.15 \\
\hline Train / Bicycle / Motorcycle & 4.34 \\
\hline Two transport modes & 7.97 \\
\hline Three transport modes & 1.45 \\
\hline Unspecified & 2.42 \\
\hline \multicolumn{2}{|l|}{ Ownership of prescribed textbook } \\
\hline Purchased new copy & 30.21 \\
\hline Purchased second-hand copy & 40.03 \\
\hline Rented a copy & 11.46 \\
\hline
\end{tabular}




\begin{tabular}{|l|r|}
\hline Used short-loan library copy & 3.72 \\
\hline Not at all - relied on PowerPoint slides & 13.84 \\
\hline Unspecified & 0.74 \\
\hline Weekly study hours & 1.70 \\
\hline None & 39.46 \\
\hline 1-3 hours & 37.25 \\
\hline 4-6 hours & 15.30 \\
\hline 7-10 hours & 6.29 \\
\hline More than 10 hours & 5.32 \\
\hline Mean (hours) & \\
\hline Frequency of not attending lectures & 5.80 \\
\hline Never & 25.00 \\
\hline Rarely & 39.14 \\
\hline Sometimes & 23.96 \\
\hline Often & 5.65 \\
\hline Always & 0.45 \\
\hline All the time & \\
\hline
\end{tabular}

Whilst Table 1 shows only 8.76 per cent (or 83 students) stayed in campus residence using the information from SASI, Table 5 rather indicates that 22.17 per cent (or 149) of students who took part in the survey reported they were staying in campus residence at the time of enrolling ECO151. The discrepancy is expected, as campus residence information was not updated immediately on SASI when some students were offered places at campus residence later in the year. Moreover, 16 per cent stayed at private residence close to campus. One worrying finding is that 28 per cent stayed at least $20 \mathrm{~km}$ away from campus. For those who did not stay at campus residence or private residence close to campus, a follow-up question was asked on their transport mode: only 24 per cent had their own cars, 26 per cent relied on lift clubs, and 34 per cent travelled with buses or mini-bus taxis. Also, 9 per cent needed two or three transport modes to go to campus.

About 70 per cent of survey participants purchased either new or second-hand copy of the prescribed textbook, 11 per cent rented a copy from the Department of Economics (the department launched a textbook leasing program in 2018 to provide 100 hard copies of the prescribed textbook for students to rent for study purpose), while it is concerning that 13.84 per cent claimed they only relied on PowerPoint slides provided by the lecturers to study. About 40 per cent of the survey participants reported spending one to three hours studying the course materials per week, whereas 37 per cent spent four to six hours. Mean and median hours were 5.32 and 4.00, respectively. Lastly, 39 per cent of survey participants reported they did not attend lectures sometimes while only 5.8 per cent said they never missed a lecture.

Figure 1 compares our digitally captured and the students' self-reported answers on lecture attendance. Mean lecture attendance (5.05) was much higher for those who claimed they never missed a class. In fact, this mean of 5.05 is statistically significant from the mean of other 
categories (at a significance level of 1\%). On the other hand, mean tutorial attendance across these self-reported lecture attendance frequency categories was quite close (ranging between 3.51 and 3.95), and these means are not statistically different from one another.

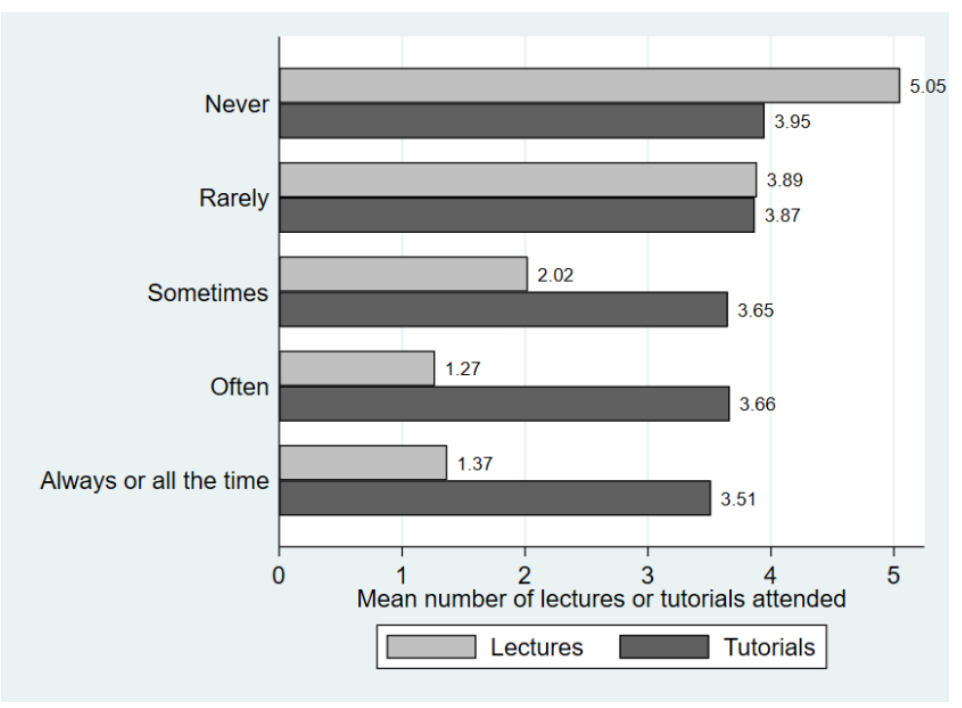

Figure 1: Mean number of lecture and tutorial attendance, by self-reported frequency of not attending lecture category

For survey participants who did not claim they never missed a lecture, they were asked to declare the reasons for not attending classes and were allowed to report more than one reason. The possible reasons are classified into three broad categories: academic, personal and institutional. Academic reasons relate to quality of lectures and tutorials, availability of online learning resources and preference to allocate time on other academic activities; institutional reasons focus on timetable and venue related issues, while personal reasons include factors such as work commitment, transportation and health.

Table 6 indicates that for the top five reasons are all academically related: "busy studying for tests" (37.28\%), "lectures are not helpful or stimulating" (28.44\%), "need to complete assignments" (21.96\%), "online learning resources on iKamva are sufficient to cope with studies" $(21.01 \%)$ and "tutorials are great that can replace lectures" $(18.33 \%)$. These findings conform to some empirical studies reviewed earlier (Devadoss and Foltz 1996; Schmulian and Coetzee 2011; Wadesango and Machingambi 2011).

Table 6: Proportion of students reporting each reason for not attending lectures (\%)

\begin{tabular}{|l|c|}
\hline Academic reasons & \\
\hline Need to study for tests & 37.28 \\
\hline Lectures are not helpful or stimulating & 28.44 \\
\hline Need to complete assignments & 21.96 \\
\hline Online learning resources on iKamva are sufficient to cope with studies & 21.01 \\
\hline
\end{tabular}




\begin{tabular}{|l|c|}
\hline Tutorials are great that can replace lectures & 18.33 \\
\hline Online learning resources on the internet (e.g, YouTube) are sufficient & 9.79 \\
\hline Do not understand the lecturer's explanation & 4.90 \\
\hline Lecture attendance does not count towards CAM & 4.90 \\
\hline Lectures are cancelled by the lecturer & 3.79 \\
\hline Institutional reasons & 7.90 \\
\hline Lecture venue is too noisy & 6.95 \\
\hline Time clashes with other modules & 5.37 \\
\hline Lecture takes place too late in the afternoon & 4.58 \\
\hline Lecture takes place too early in the morning & 4.11 \\
\hline Lecture venue is full with no spare seats & \\
\hline Personal reasons & 12.64 \\
\hline Unreliable mode of transport that was not on time & 10.90 \\
\hline Illness & 9.79 \\
\hline Laziness & 9.64 \\
\hline Need to work & 6.64 \\
\hline Do not have money to pay for the transport mode to come to campus & 5.21 \\
\hline Simply do not like to attend lectures & 5.06 \\
\hline Family commitments & 2.53 \\
\hline Prefer to spend the time to socialise with friends & \\
\hline
\end{tabular}

The fact that "busy studying for tests" was the top reason is not surprising, given the results in Table 4 suggest that lecture attendance was extremely low on Fridays, while both module tests took place on a Friday. Hence, it is highly likely some students opted to skip classes to find more time to study for tests (similar findings were observed by Foltz 1996 as well as Paisey and Paisey 2004). That nearly 30 per cent of students claimed lectures are not helpful or stimulating are concerning as this reason relates to lecture and lecturer quality. Looking at the other popular reasons, some students may struggle with time management as they transitioned from school to university, thereby not coping with completing assignments on time. That online resources and tutorials are regarded as substitutes of sit-down lectures mean it is worth investigating whether blended learning boost or rather discourage lecture attendance (Riffell and Sibley 2004).

The top institutional reason for not attending lectures was "lecture venue is too noisy" (7.90\%), while the most dominant personal reason was "unreliable mode of transport that was not on time" (12.64\%). The latter result makes sense, as Table 5 shows only a small proportion of students had their own motor vehicles. This result also helps explain the much lower attendance on Mondays 15:30-16:30 (Table 4).

Before proceeding to the econometric analysis, Table 7 and Figure 2 show the mean CAM, examination and final marks by selected characteristics. Students who enrolled Economics and Mathematics in Matric and enjoyed higher entry points were associated with significantly better 
ECO151 performance. Higher lecture and tutorial attendance and better ECO152 marks were associated with significantly higher ECO151 examination marks, except that students would need to attend all four tutorials to enjoy statistically significantly better results. Furthermore, students who rented the prescribed textbooks performed best on average along with those who purchased new or second-hand copies, whereas the remaining students who relied on short-loan library copies (which they were only allowed to use for two hours maximum inside the library) or PowerPoint slides performed significantly worse.

Table 7: Mean CAM, examination and final marks by selected characteristics

\begin{tabular}{|c|c|c|c|c|}
\hline Characteristic & Category & CAM & $\begin{array}{c}\text { Exam } \\
\text { mark }\end{array}$ & $\begin{array}{l}\text { Final } \\
\text { mark }\end{array}$ \\
\hline \multirow[t]{2}{*}{ Enrolled Economics in Matric } & Yes & 60.72 & 56.58 & 60.46 \\
\hline & No & $55.49^{*}$ & $52.66^{*}$ & $56.96^{*}$ \\
\hline \multirow[t]{2}{*}{ Enrolled Mathematics in Matric } & Yes & 57.42 & 54.31 & 58.42 \\
\hline & No & $50.09^{*}$ & $45.54^{*}$ & $50.93^{*}$ \\
\hline \multirow[t]{4}{*}{ Entry points } & Below 35 points & 49.97 & 47.01 & 51.57 \\
\hline & 35-39 points & $55.38^{*}$ & $51.11^{*}$ & $55.44^{*}$ \\
\hline & $40-44$ points & $57.39^{*}$ & $54.87^{*}$ & $58.94^{*}$ \\
\hline & 45 points or above & $64.46^{*}$ & $60.88^{*}$ & $64.80^{*}$ \\
\hline \multirow[t]{3}{*}{ Tutorial attendance } & Never, once or twice & 27.07 & 48.33 & 48.26 \\
\hline & Three times & $55.48^{*}$ & 48.35 & 52.59 \\
\hline & Four times & $64.64^{*}$ & $55.78^{*}$ & $60.27^{*}$ \\
\hline \multirow[t]{5}{*}{ ECO152 final mark } & Failed: Below 50 marks & 36.52 & 40.16 & 45.97 \\
\hline & Pass: $50-59$ marks & $54.88^{*}$ & $49.31^{*}$ & $53.60^{*}$ \\
\hline & Pass: 60-69 marks & $63.83^{*}$ & $57.32^{*}$ & $61.34^{*}$ \\
\hline & Pass: $70-74$ marks & $70.61^{\star}$ & $64.32^{*}$ & $67.83^{*}$ \\
\hline & Pass: 75-100 marks & $75.37^{*}$ & $71.74^{*}$ & $74.43^{*}$ \\
\hline \multirow[t]{5}{*}{ Purchased the prescribed textbook } & $\begin{array}{l}\text { Purchased new or second- } \\
\text { hand copy }\end{array}$ & 63.08 & 55.56 & 59.74 \\
\hline & Rented a copy & 63.96 & 57.69 & $61.23^{*}$ \\
\hline & Used short-loan library copy & $54.37^{*}$ & $48.73^{*}$ & $52.08^{*}$ \\
\hline & Not at all & $57.27^{\star}$ & $49.26^{*}$ & $53.91^{*}$ \\
\hline & Did not take part in the survey & $45.09^{*}$ & $51.04^{*}$ & $55.33^{*}$ \\
\hline \multirow[t]{2}{*}{ Busy studying for tests } & Yes & 63.96 & 54.72 & 59.72 \\
\hline & No & $60.26^{*}$ & 53.65 & 57.48 \\
\hline \multirow[t]{2}{*}{ Lectures are not helpful or stimulating } & Yes & 61.04 & 53.35 & 57.50 \\
\hline & No & 61.88 & 54.34 & 58.66 \\
\hline \multirow[t]{2}{*}{ Need to complete assignments } & Yes & 62.33 & 54.12 & 58.63 \\
\hline & No & 61.44 & 54.03 & 58.24 \\
\hline \multirow{2}{*}{$\begin{array}{l}\text { Online learning resources on iKamva } \\
\text { are sufficient to cope with studies }\end{array}$} & Yes & 62.93 & 51.88 & 57.58 \\
\hline & No & 61.29 & 54.64 & 58.53 \\
\hline \multirow{2}{*}{$\begin{array}{l}\text { Tutorials are great that can replace } \\
\text { lectures }\end{array}$} & Yes & 59.83 & 47.92 & 54.39 \\
\hline & No & 62.04 & $55.42^{*}$ & $59.20^{*}$ \\
\hline
\end{tabular}

Note: the first category in each characteristic represents the reference category.

* The mean is statistically significant from the reference category at $\alpha=5 \%$. 


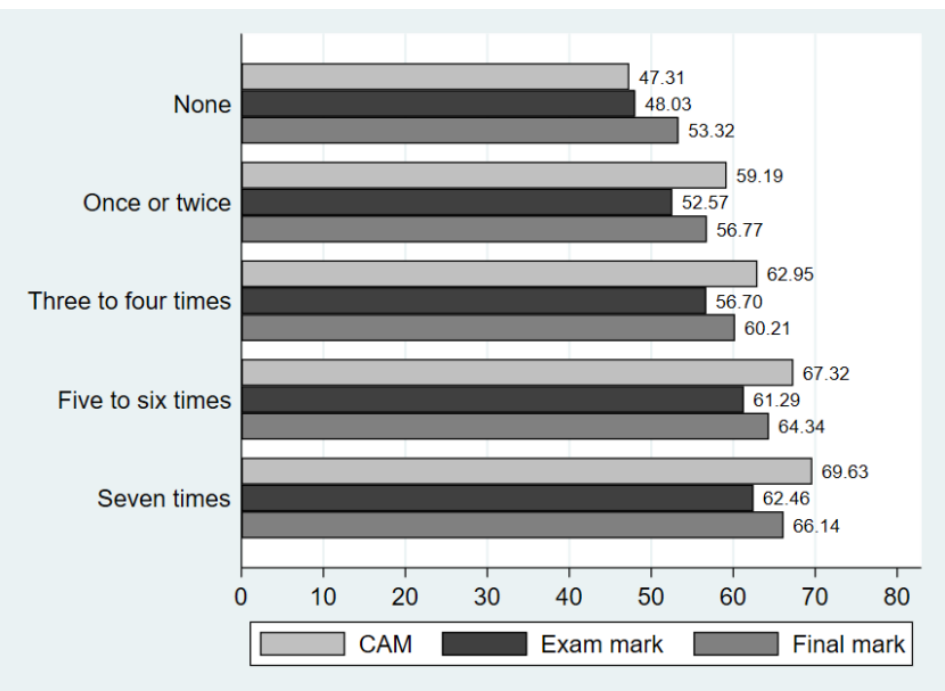

Note: all three means in the other categories are statistically significant from the respective means in the reference category (Lecture attendance frequency: none) at $\alpha=5 \%$.

Figure 2: ECO151 mean CAM, examination mark and final mark by lecture attendance

Lastly, looking at the relationship between the top five reasons of not attending lectures and ECO151 performance, those who claimed they were busy studying for tests had their CAM 3.7 marks significantly higher, that is, somehow, they enjoyed an "advantage" by skipping lectures to focus on studying for tests. Those who reported they did not attend lectures because they were of the opinion that tutorials can replace lectures suffered significantly lower examination mark (of 7.5 marks) and final mark (of nearly five marks), compared with the reference category (students who claimed it was not the reason for not attending lectures).

\section{Multivariate analysis}

In the final part of the empirical analysis, two-step Heckman regressions are run to explain the impact of various explanatory variables on examination mark. With regard to the results of the probit regressions on probability to qualify and write the examination, four explanatory variables are statistically significant with positive impact: students of the Coloured ethnicity group, Economics studies in Matric, lecture attendance and tutorial attendance. The findings on the two attendance variables are the same as the two local studies that also adopted the two-step Heckman approach (Dlomo et al. 2011; Horn et al. 2011). The positive impact of the Coloured and Matric dummy variables somehow is opposite of what was found by Horn et al. (2011); nonetheless, the latter study examined the SU students whose ethnic and school characteristics were very different from those of the UWC students. 
Table 8: Heckman two-step regressions on the ECO151 examination mark

\begin{tabular}{|c|c|c|c|}
\hline & [I] & [III] & [III] \\
\hline \multicolumn{4}{|l|}{ Examination mark } \\
\hline Dummy: Male & & -0.9068 & -0.5368 \\
\hline Dummy: Coloured & & 0.2226 & 0.4482 \\
\hline Dummy: Asian / Indian / White & & -1.4084 & -1.0287 \\
\hline Age in years & & -3.0810 & $-3.3305^{*}$ \\
\hline Age in years squared & & 0.0579 & 0.0642 \\
\hline Dummy: Matric province - other than Western Cape & & 0.2505 & 0.2147 \\
\hline Dummy: Matric Economics & & 0.5092 & 0.4397 \\
\hline Dummy: Matric Mathematics & & $4.4396^{\star *}$ & $4.4074^{* *}$ \\
\hline Entry points & & 0.0652 & 0.1369 \\
\hline Entry points squared & & 0.0036 & 0.0026 \\
\hline ECO152 final mark & & $0.6110^{\star \star \star}$ & $0.5943^{* \star *}$ \\
\hline Lecture attendance & $2.2069^{* * *}$ & $1.2222^{\star \star \star}$ & $1.0899^{* * *}$ \\
\hline Tutorial attendance & $5.5396^{\star \star \star}$ & $3.1385^{\star \star \star}$ & $3.2585^{* \star *}$ \\
\hline Dummy: took part in the survey & & & 0.0878 \\
\hline Dummy: purchased or rented prescribed textbook & & & 1.5601 \\
\hline Dummy: stay at residence on or close to campus & & & 0.1389 \\
\hline Dummy: need two to three transport mode & & & -0.5744 \\
\hline Dummy: tutorials are great and can replace lectures & & & $-4.3869^{* \star *}$ \\
\hline Lambda & $12.3457^{\star \star \star}$ & $11.6666^{\star \star \star}$ & $11.7978^{\star \star \star}$ \\
\hline Constant & $27.5186^{\star \star *}$ & 28.2223 & 29.5127 \\
\hline \multicolumn{4}{|l|}{ Selection equation: qualified and wrote the examination } \\
\hline Dummy: Male & \multicolumn{3}{|c|}{-0.1581} \\
\hline Dummy: Coloured & \multicolumn{3}{|c|}{$0.5575^{\star \star}$} \\
\hline Dummy: Asian / Indian / White & \multicolumn{3}{|c|}{0.0268} \\
\hline Age in years & \multicolumn{3}{|c|}{-0.3285} \\
\hline Age in years squared & \multicolumn{3}{|c|}{0.0062} \\
\hline Dummy: Matric province - other than Western Cape & \multicolumn{3}{|c|}{0.3537} \\
\hline Dummy: Matric Economics & \multicolumn{3}{|c|}{$0.4352^{*}$} \\
\hline Dummy: Matric Mathematics & \multicolumn{3}{|c|}{0.0897} \\
\hline Entry points & \multicolumn{3}{|c|}{-0.2928} \\
\hline Entry points squared & \multicolumn{3}{|c|}{0.0037} \\
\hline Lecture attendance & \multicolumn{3}{|c|}{$0.2357^{\star \star \star}$} \\
\hline Tutorial attendance & \multicolumn{3}{|c|}{$1.0486^{\star \star \star}$} \\
\hline Constant & \multicolumn{3}{|c|}{7.5604} \\
\hline R-squared & 0.1450 & 0.4045 & 0.4161 \\
\hline Adjusted R-squared & 0.1419 & 0.3943 & 0.4025 \\
\hline F-statistic & 46.87 & 39.69 & 30.49 \\
\hline Number of observations & 833 & 833 & 833 \\
\hline
\end{tabular}

"*** Significant $1 \% \quad$ "* Significant at $5 \% \quad$ "Significant at $10 \%$

Moving on to the Heckman regressions on examination mark, before controlling for differences in other characteristics, regression [I] shows that both lecture and tutorial attendance are associated with a significantly positive impact on examination performance. This finding is once again in line with the earlier conducted local empirical studies (Horn and Jansen 2009; 
Dlomo et al. 2011; Horn et al. 2011).

Upon controlling for differences in other characteristics, regression [II] shows that these two attendance variables remain statistically significant but their respective coefficients have almost halved. In addition, those with Matric Mathematics obtained 4.4 marks higher than those with Mathematical Literacy, whereas students who scored one mark higher in the ECO152 final mark obtained an additional 0.61 marks in ECO151 final examination, ceteris paribus. These two results are both statistically significant, and are expected, as it was proven in numerous empirical studies that students with Matric Mathematics and better performance in first-year Economics also performed better in higher-level Economics modules.

The abovementioned four explanatory variables remain statistically significant with the same coefficient sign in regression [III], after the explanatory variables in connection with the survey were added. Two more explanatory variables are also statistically significant in regression [III], namely age (older students performed worse) and a dummy variable which indicates the students reported they missed lectures as they believed tutorials could replace lectures. The latter result conforms to the findings in Table 7 as discussed earlier. In fact, the coefficient in the regression suggests that students who assumed tutorials can replace lectures suffered in the examination, as they scored 4.4 marks lower. This finding strongly implies that lectures and tutorials are not perfect substitutes in terms of students' learning.

Regression [III] also shows that students living in residence on or close to campus, and those who purchased or rented the prescribed textbook performed better, while students who required at least two transport modes to travel to campus performed worse. However, all these results are statistically insignificant. Finally, in all three regressions, lambda is statistically significant; that is, sample selection bias exists and it is a correct decision to adopt the Heckman two-step approach to control for the fact that not all students qualified and wrote the examination.

\section{CONCLUSION}

This is the first South African study that comprehensively investigated the main reasons for first-year Economics students not attending lectures and the subsequent impact on academic performance. After examining the personal profile, school characteristics and university programme characteristics, the study examined the lecture and tutorial attendance of 947 students in the sample who enrolled ECO151 Microeconomics in 2019. It was also found that lecture attendance was extremely low in the late afternoon 15:30-16:30 and Friday periods.

The key highlights of the survey (participated by 672 students) were as follows: nearly 40 per cent resided at residence on or close to campus, about 10 per cent used two transport modes 
to travel to campus, 14 per cent did not purchase or use the prescribed textbook by merely relied on PowerPoint slides to study, and only 5.8 per cent self-reported they never missed a lecture. For the remaining 94.2 per cent survey participants who admitted they missed at least one lecture, they were asked to declare the main reasons for not attending classes, and the top five reasons are "busy studying for tests" (37.28\%), "lectures are not helpful or stimulating" (28.44\%), "need to complete assignments" (21.96\%), "online learning resources on iKamva are sufficient to cope with studies" (21.01\%) and "tutorials are great that can replace lectures" $(18.33 \%)$.

The multivariate analysis showed that both lecture attendance and tutorial attendance had a positive and significant impact on the probability of qualifying to write the final examination and examination mark. Students with Matric Economics and better ECO152 final mark in the first semester performed significantly better in ECO151 examination. Lastly, those who regarded "tutorials were great and could replace lectures" eventually paid a heavy price in the examination, as they scored more than four marks significantly lower, compared with students who did not think tutorials and lectures could replace each other. Our analysis here further supports the previous literature on the importance of lecture attendance for academic results but go further to investigate why students do no attend lectures in the first place.

\section{RECOMMENDATIONS}

With our questionnaire, we attempted to identify some reasons why students are absent from lectures. First, given the large proportion of students that indicated that "lectures are not helpful or stimulating" and that "tutorials are replacements for the lectures", we suggest changes made to teaching. The combination of these two reasons suggest that students prefer examples like done in tutorials rather than explanations/summaries of textbooks that form lectures. One option is to experiment with flipped classroom experiences or case studies in lectures moving away from the traditional lecture structure. As new technology is available to capture and measure lecture attendance through card readers, it becomes possible to count lecture attendance as part of the CAM. However, previous literature that suggest academic curiosity in students is important and should be interrogated more in future research. This is an aspect we did not investigate deeply. Our research is limited by the questions asked in the questionnaire and would require more primary research like interviews with students to determine deeper factors like academic curiosity.

Students also wrongly believe that online material are replacements for the textbook they perform significantly worse. Given the poverty context from which many of our students come, an expanded textbook renting program should be considered. This can be extended to 
other departments as well. In January 2019, the NFSAS scheme changed from a controlled manner where it paid specifically for textbooks and materials to a cashable allowance (Kharwa 2020). If this is to continue, a rent-a-textbook program is sustainable for students rather than large payments for the textbooks needed. This further supports our call for more research on academic curiosity since the problem may not lie with content but student engagement with the material.

Given our results on low attendance in late afternoons and Fridays, there may be a need to drastically adjust the timetable and even exclude certain slots from timetable. However, given the limited slots that are available on the timetable one could further consider spending specific days (e.g., Mondays to Wednesdays) for first-year teaching to save students' transportation time and money for travelling to campus. The university could also consider the expanding of their bus services to regions further from the direct region of campus. This will also need to be verified and supported by other Departments and Faculties which limits the opportunity to adjust in this way.

Our final recommendation relates to the finding that students stated that they missed lectures as they were busy with assignments or test preparation. This result implies students are ill-prepared for the shift from high school to university where the workload is much higher. It could also indicate that students have poor time management skills and do not realise how much work is needed to pass courses. One way to mitigate these effects is to introduce students to time management techniques during orientation or to develop a "student-workload model" to ensure balance between courses and time required of students.

\section{ACKNOWLEDGEMENT}

The authors would like to thank postgraduate student Ms Shinice Jackson for the assistance to capture the primary survey data.

\section{NOTE}

1. Ceteris paribus is an economic term meaning all other things being equal.

\section{REFERENCES}

Braak, D. 2015. "An exploratory investigation into factors affecting class attendance in a hospitality management module." Unpublished study. http://iiespace.iie.ac.za/handle/11622/39. (Accessed 22 May 2019).

Devadoss, S. and J. Foltz. 1996. "Evaluation of factors influencing student class attendance and performance." American Journal of Agricultural Economics 78(3): 499-507.

Dlomo, Z., A. Jansen, M. Moses, and D. Yu. 2011. "Investigating the significance of the 2008 Matric curriculum on first-year economics performance." South African Journal of Higher Education 25(4): 696-709. 
Dolnicar, S. 2005. "Should we still lecture or just post examination questions on the web? The nature of the shift towards pragmatism in undergraduate lecture attendance." Quality in Higher Education 11(2): 103-115.

Dos Reis, K. and D. Yu. 2018. "Peer mentoring: Enhancing economics first years' academic performance." South African Journal of Higher Education 32(6): 234-250.

Edwards, L. 2000. "An econometric evaluation of academic development programme in economics." South African Journal of Economics 68(3): 456-483.

Friedman, P., F. Rodriguez, and J. McDomb. 2001. "Why students do and do not attend classes: Myths and realities." College Teaching 49(4): 124-133.

Horn, P. and A. Jansen. 2009. "Tutorial classes - why bother? An investigation into the impact of tutorials on the performance of economics students." South African Journal of Economics 77(1): 179-189.

Horn, P., A. Jansen, and D. Yu. 2011. "Factors explaining the academic success of second-year economics students: An exploratory analysis." South African Journal of Economics 79(2): 202210.

Jordaan, Y. 2009. "Influencing factors on lecture attendance at a tertiary institution." South African Journal of Higher Education 23(1): 98-112.

Kharwa, M. 2020. "Opinion: How NSFAS cash policy closed the book on students and small businesses." Fin24.com. https://www.fin24.com/Opinion/opinion-how-nsfas-cash-policy-closedthe-book-on-students-and-small-businesses-20200313. (Accessed 19 May 2020).

Kottasz, R. 2005. "Reasons for student non-attendance at lectures and tutorials: An analysis." Investigations in University Teaching and Learning 2(2): 5-16.

Longhurst, R. J. 1999. "Why aren't they there? Student absenteeism in a further education college." Journal of Further and Higher Education 23(1): 61-80.

Massingham, P. and T. Herrington. 2006. "Does attendance matter? An examination of student attributes, participation, performance and attendance." Journal of University Teaching and Learning Practice 3(2): 83-103.

Moore, R. 2006. "Class attendance: How students' attitudes about attendance relate to their academic performance in introductory science classes." Research and Teaching in Developmental Education 23(1): 19-33.

Moore, S., C. Armstrong, and J. Pearson, J. 2008. "Lecture absenteeism among students in higher education: A valuable route to understanding student motivation." Journal on Higher Education Policy and Management 30(1): 15-24.

Paisey, C. and N. J. Paisey. 2004. "Student attendance in an accounting module - reasons for nonattendance and the effect on academic performance at a Scottish University." Accounting Education 13(S1): 39-53.

Parker, K. 2006. "The effect of student characteristics on achievement in introductory microeconomics in South Africa." South African Journal of Economics 74(1): 137-149.

Riffell, S. K. and D. F. Sibley. 2004. "Can hybrid course formats increase attendance in undergraduate environmental science courses?" Journal of Natural Resources and Life Sciences Education 33(1): $16-20$

Romer, D. 1993. “Do students go to class? Should they?" Journal of Economic Perspectives 7(3): 167174.

Schmulian, A. and S. Coetzee. 2011. "Class absenteeism: Reasons for non-attendance and the effect on academic performance." Accountancy Research Journal 24(2): 178-194.

Schreiber, B. and D. Yu. 2016. "Exploring student engagement practices at a South African university: Student engagement as reliable predictor of academic performance." South African Journal of Higher Education 30(5): 157-175.

Siegfried, J. J. and R. Fels. 1979. "Research on teaching college economics: A survey." Journal of 
Economic Literature 17(3): 923-969.

Smith, L. 2009. "An analysis of the impact of pedagogic interventions in first-year academic development and mainstream courses in microeconomics." South African Journal of Economics 77(1): $162-178$.

Smith, L. and L. Edwards. 2007. "A multivariate evaluation of mainstream and academic development courses in first-year microeconomics." South African Journal of Economics 75(1): 99-117.

Van der Merwe, A. 2006. "Identifying some constraints in first year economics teaching and learning at a typical South African university of technology." South African Journal of Economics 74(1): $150-159$.

Van Walbeek, C. 2004. "Does lecture attendance matter? Some observations from a first-year economics course at the University of Cape Town." South African Journal of Economics 72(4): 861-883.

Vidler, D.C. 1980. "Curiosity, academic performance, and class attendance.” Psychology Reports 47(3): 589-590.

Wadesango, N. and S. Machingambi. 2011. "Causes and structural effects of student absenteeism: A case study of three South African universities.” Journal of Social Sciences 26(2): 89-97.

Wyatt, G. 1992. "Skipping class: An analysis of absenteeism among first-year college students." Teaching Sociology 20(3): 201-207.

Woodfield, R., D. Jessop. and L. McMillan. 2006. "Gender differences in undergraduate attendance rates." Studies in Higher Education 31(1): 1-22. 